\title{
Corporate Governance, Investment And Business Growth
}

\author{
Tarek Miloud, INSEEC Business School, France
}

\begin{abstract}
The purpose of this study is to bridge the gap between theory and corporate governance practices in selected emerging and developed economies, and assess its impact on corporate growth and productivity. Our investigation yields a negative relationship between corporate governance and investment levels and GDP growth in these countries.
\end{abstract}

Keywords: Investment; Corporate Governance Indicators; Agency Theory; Economic Growth

\section{INTRODUCTION}

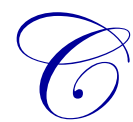

ioffi (2000) defines corporate governance (CG) as a nexus of institutions defined by company law, financial market regulation, and labor law. According to La Porta, Lopez, Shleifer and Vishny (2000) CG is to a large extent, a set of mechanisms through which outsider investors protect themselves from expropriation by insiders. It means the system formed by all processes, customs, policies, laws and institutions is designed to fit the way the company is managed and controlled. Depending on the objectives set to govern the company, this system is called to regulate and manage the relationships among the stakeholders including the board of directors and the shareholders. It also deals with those mechanisms and controls that are designed to reduce or eliminate the principal-agent problem in the organization. CG is a crucial standard for establishing the striking investment environment which is needed by competitive companies to strengthen their position in efficient financial markets. Good corporate governance is essential to the economies with wide business background and sustainable economic growth. It also creates a favorable investment climate and facilitates the success of entrepreneurship.

The governance structure of a country aims to terminate the expropriation of the minority shareholders by managers and large shareholders. La Porta et al. (2000) argue that in different jurisdictions, rules protecting investors come from different sources, including company, security, bankruptcy, competition laws, and also from stock exchange regulations and accounting standards. Since the Cadbury report (1992), CG has gained momentum worldwide because of numerous scandals that have affected the world of business, insufficient disclosure and unethical business practices. In continental Europe, countries that followed civil law have developed corporate governance frameworks that focused on stakeholders. Solomon (2010) stresses that the role of CG in those countries was to balance the interests of employees, managers, creditors, suppliers, customers and the wider community. This model is better known as the insider model of corporate control. However, in common law countries the CG system (outsider model) is focused on shareholders' interests. The need to attract foreign investors and protect their interests obliges developing countries to implement strict CG fundamentals for their own firms.

Güler and Croxther (2009) consider CG as an environment of trust, ethics, moral values and confidence - as a synergic effort of all the stakeholders - and the corporate sector. In order to fully understand this new complex issue and grasp the differences and similarities in corporations over the world, we must take into account the geographical environment and cultural factors. In these countries, according to La Porta, Lopez-De-Silanes and Shleifer (1999), companies are controlled by the large shareholders. In highly concentrated ownership environments appears a first conflict of interest between shareholders and management. This relationship turns into a second conflict between small shareholders and controlling shareholders.

Shleifer and Vishny (1997) argue that good CG mechanisms generates investor goodwill and confidence. If these mechanisms did not exist or did not function properly, outside investors would not lend to firms or buy their equity securities. As thus, businesses would be forced to rely entirely on their own internally generated cash flows and 
accumulated financial resources to finance ongoing operations as well as profitable investment opportunities. Therefore the overall economic performance would likely suffer because many good business opportunities would be missed and financial distress at individual firms would spread quickly to other firms, employees, and consumers.

Several studies have been done in developed countries to investigate the relationship between CG, investment and business growth. However, very few studies examine this relationship in emerging markets. The purpose of this study is to eliminate the gap between theory and practice about CG in eastern countries, which have transitioned from a socialist to a market economy. In these countries, practice of CG is still new and underdeveloped in comparison with the growth of companies and the stock market. Moreover, the transparency of disclosure practices is still poor and the concentration of power remains in the hands of directors as well as other key management connections. More broadly, this study examines the impacts of CG mechanisms on investment and business growth in the Eastern European countries. This economic area is an especially suitable laboratory for studying the effect of firm-level governance on firm performance. The remainder of the paper is organized as follows: We discuss the literature review and we present our hypotheses in section 2. Section 3 discusses the data and methodology. Section 4 reports our empirical results and analysis. We present comments in Section 5.

\section{LITERATURE REVIEW AND HYPOTHESIS DEVELOPMENT}

\subsection{Corporate Governance and the Board of Directors}

Tirole (2001) stresses that CG is the design of institutions that induces or forces managers to internalize the welfare of stakeholders. To achieve the strategic goals in a company, we need to establish a combination of various mechanisms. According to John and Senbet (1998), CG structures can be divided into internal and external structures. The board of directors is one type of internal governance structure. It assumes the decision making and the monitoring role in the company. Agency theory is the central theme of the stream of research related to the monitoring role of the board. Fama (1980) argues that agency problems are generated by the separation of the risk-bearing of equity owners and the management function. In other words, the principal bears the risk while the agent carries out the operation. According to Fama and Jensen (1983), the stockholders delegate most of the decision and control functions to the Board of Directors, which in turn delegates most of its decision and control functions to the management. Consequently, two layers of agency relationship emerge. One, between the stockholders and the Board and another one between the Board and the management.

In a legal perspective, according to Zahra and Pearce (1989), the Board's mission is to protect the interests of shareholders and manage the firm without interfering in the daily management. However, Jensen (1993) shows that internal control structure reacts too late and takes too long to enact major changes. John and Senbet (1998) asset that director independence, diligence and expertise are imperative to Board effectiveness. In contrast, Hart (1995) stresses that nonexecutive directors prove a kind of loyalty with regard to the management which elects them. Thus, to force the managers to work in favor of shareholders, the presence of a block holder in ownership structure appears to be one of the key elements of CG and its effectiveness. Agrawal and Mandelker (1990) suggest that the concentration of ownership is a guarantee of effective control by shareholders. The study by Mitton (2002) refutes this thesis, because controlling shareholders themselves may engender stronger motivation to expropriate minority shareholders. Gennaioli, Shleifer and Vishny (2012) argue that ownership concentration assures the protection of the minority shareholders, who are generally interested in higher profits and therefore in their maximization, which covers the agency problems.

The ownership structures vary considerably across the European economies. In France for example, families control more than $50 \%$ of the voting rights in firms. In such case, Franks and Mayer (1998) support the idea that control will be concentrated in the hands of the owner himself. With a pyramidal structure, Barca and Trento (1997) argue that a family uses a firm that it already controls to set up new firms with a minimum investment level. In the rest of Europe, Gennaioli et al. (2012) observe that the companies are usually controlled by the founder. They point out that minority ownership has a higher level of effectiveness in a strong legal environment which protects the minority shareholders rights. 


\subsection{Agency Costs and Monitoring}

Jensen and Meckling (1976) describe various sources of conflict between the agent (manager) and the principal of the firm. The agent may select to invest costly capital on a low-risk project, thus minimizing its present value. The reduction in the principal's welfare arising from this divergence creates an additional cost of an agency relationship known as "residual loss". They define agency costs as the sum of the principal's monitoring expenditures, the agent's bonding expenditures and the residual loss. The management's risk aversion is a source of agency costs. For, if the management chooses a "safe" investment through expenses capital, the value of the project being lower, this leads to decrease value creation in the firm. To enrich the debate, Jensen (1986) enlists his free cash flow theory to study the relationship between free cash flow and agency costs. He argues that managers choose to reinvest the free cash rather than return it to investors.

The debate on agency issues was widely discussed in the literature, the most important ones being agency costs caused by separation of ownership and control. Fama (1980) stresses that shareholders are able to diversify their investment portfolio between different firms with relatively low costs. Moreover, given a competitive managerial labor market, managers may expend great efforts to ensure the success and survival of the firm. Otherwise, the shareholders will carry on direct or indirect pressures. Fama and Jensen (1983) underline that shareholders with diversified investment portfolios are willing to delegate the management control to other agents. According to Shleifer and Vishny (1997), it is easier to expropriate an investor without law protection, using a direct form such as cashing out or transfer pricing. In emerging markets, managers can easily expropriate funds, using indirect approaches. Morck, Shleifer and Vishny (1988) stress that various internal stakeholders of a business (managers, employees) tend to develop strategies with a view to maintain their status in the firm. The objective, often unspoken or unconscious, is to carry out costly replacements. Leaders can thus develop a strategy that makes them a little more critical upon the functioning of the company.

\subsection{The Control of Agency Problem?}

According to Jensen (1993), the conflicts of interests between investors and managers are still increasing in modern companies. In order to align the interests of both parties, the owners need to initiate incentive contracts for the managers and an effective monitoring system within the firm. The literature suggests several mechanisms to achieve this objective, such as dismissal threats in case of poor performance, stock options and equity ownership. Fama and Jensen (1983) argue that monitoring belongs to the majority shareholders for ratifying and monitoring important decisions and setting rewards. Because, they have the power to reduce considerably the agency problem. In contrast, when there is a dispersed ownership, the management becomes uncontrollable.

Denis and Sarin (1999) point out that, if governance mechanisms are respected, there is no significant link between individual mechanism of managers and their companies' performance. They add that solving agency problems and reducing agency cost can be done through managerial labor market and through providing stimulus to encourage managers. On the other hand, Weisbach (1988) stresses that Board of Directors is a prevailing organizational form within the decision control system, with the authority to hire, fire, set compensation schemes and control important firm decisions.

Morris (1989) believes that the lack of separation between ownership and management leads the firm to suffer from cloudy financial vision. More recently, Franzini (2009) claims that, from economic literature, the main consequence is that CG affects economic growth and investment levels. He argues that good CG practices facilitate corporate financing, improve their performance and reduce their cost of capital. In conclusion, we argue that good CG level refers to extensive CG regulations achieved by the initial CG mechanisms. The above arguments conform to the following testable hypothesis:

Hypothesis (1): The CG levels are positively correlated to the investment aggregate level.

Hypothesis (2): The CG levels are positively correlated to the growth rate. 


\subsection{Sample}

\section{THE RESEARCH DESIGN}

This study uses panel data obtained from the European Bank for Reconstruction and Development (EBRD) available online from 2003 until 2013. EBRD has gathered a set of CG indicators which can be found in the Corporate Governance Legislation Assessment Project. These indicators will represent the independent variables used in order to carry out the regressions. This assessment was made by law firms that operate in the EBRD area and it comprises six main interest groups.

\subsection{Variable Measurement and Models Specifications}

The sample was gathered from four world geographic regions. To test our hypothesis, we carry out a regression analysis using two dependent variables: (i) the level of investment (Inv) measured as percentage of GDP; (ii) the growth in real GDP for the second hypothesis $(G r G D P)$. Control variables include six main interest groups $(I G)$, general index (cgIndex), the effectiveness of CG components (cgEffec), the rate of money growth (Mgr), price liberalization (Pricelib), privatization (Priv), geographic regions ( $r e g$ ) of every country, natural logarithm of the GDP $(\log G d p)$ and a dummy variable for the legal origin (legor).

We run two regressions for each individual dependent variable, one for the aggregate CG index and the other for the CG components. We present below our four regressions, where the subscript $t$ indicates a time-changing variable and $i$ denotes a changeable variable across countries.

Empirical model used to test hypothesis 1:

$$
\begin{aligned}
& \text { Inv }=\beta_{0}+\beta_{1} \text { cgIndex }_{i}+\beta_{2} \text { cgEffec }_{i}+\beta_{3} \text { Legor }_{i}+\beta_{4} \text { Priv }_{i t}+\beta_{5} \text { Pricelib }_{i t}+\beta_{6} \text { logGdp }_{i t}+\beta_{7} \text { Mgr }_{i t} \\
& +\beta_{8} \operatorname{Lendr}_{i t}+\beta_{9} \operatorname{Reg}_{i}+\varepsilon_{i t} \\
& I N V=\beta_{0}+\beta_{1} c g 1_{i}+\beta_{2} c g 2_{i}+\beta_{3} c g 3_{i}+\beta_{4} c g 4_{i t}+\beta_{5} c g 5_{i}+\beta_{6} c g 6_{i}+\beta_{7} c g e f f e c_{i}+\beta_{8} \text { Legor }_{i}+\beta_{9} \text { Priv }_{i t} \\
& +\beta_{10} \text { Pricelib }_{i t}+\beta_{11} \log _{\text {Gdp }}+\beta_{12} \text { Mgr }_{i t}+\beta_{13} \text { Lendr }_{i t}+\beta_{14} \text { Reg }_{i}+\varepsilon_{i t}
\end{aligned}
$$

Empirical model used to test hypothesis 2:

$$
\begin{aligned}
& G D P=\beta_{0}+\beta_{1} \text { cgIndex }_{i}+\beta_{2} \text { cgEffec }_{i}+\beta_{3} \text { cgLegor }_{i}+\beta_{4} \text { Priv }_{i t}+\beta_{5} \text { pricelib }_{i t}+\beta_{6} \log _{\text {Gdp }}+\beta_{i t}+\beta_{7} \text { Mgr } r_{i t} \\
& +\beta_{8} \operatorname{Lendr}_{i t}+\beta_{9} \operatorname{Reg}_{i}+\varepsilon_{i t} \\
& G D P=\beta_{0}+\beta_{1} c g 1_{i}+\beta_{2} c g 2_{i}+\beta_{3} c g 3_{i}+\beta_{4} c g 4_{i t}+\beta_{5} c g 5_{i}+\beta_{6} c g 6_{i}+\beta_{7} \operatorname{cgeffec}_{i}+\beta_{8} \text { Legor }_{i}+\beta_{9} \text { Priv }_{i t} \\
& +\beta_{10} \text { Pricelib }_{i t}+\beta_{11} \log _{\text {Gdp }}+\beta_{12} \text { Mgr }_{i t}+\beta_{13} \text { Lendr }_{i t}+\beta_{14} \text { Reg }_{i}+\varepsilon_{i t}
\end{aligned}
$$

\section{EMPIRICAL RESULTS}

\subsection{Corporate Governance Level and Investment}

Table 1 presents results for the first hypothesis. The CG index is significant with a p-value of 0.033 and is also negatively correlated with investment. Indicating that one unit increases in the index, will reduce the investment by $0.3 \%$. We observe a positive correlation between legal origin and investment. The variable $\log G D P$ indicates that an increase in the investment level results in higher GDP of the country. The regression indicates that investment level in region 1 is more important than in region 4 . However, the coefficient is significant only at $5 \%$ level. The result is significant for the regions 2 and 3. 
Table 1. Regression results for CG levels and investment aggregate level

\begin{tabular}{|c|c|c|}
\hline & Model 1 & Model 2 \\
\hline Intercept & $0.767\left(6.11^{\alpha}\right)$ & $0.83\left(6.25^{\alpha}\right)$ \\
\hline$C G_{1}:$ Foundation for Cg framework & & $-43.31\left(-1.56^{\gamma}\right)$ \\
\hline$C G_{2}:$ Shareholders rights & & $0.14\left(0.08^{\gamma}\right)$ \\
\hline$C G_{3}:$ Shareholder treatment & & $-6.34(-0.30)$ \\
\hline$C G_{4}:$ Shareholders role & & $4.81(0.31)$ \\
\hline$C G_{5}:$ Transparency & & $-21.48\left(-2.22^{\beta}\right)$ \\
\hline$C G_{6}:$ Board responsibility & & $-6.72(-0.38)$ \\
\hline cgIndex: General index & $-0.279\left(-1.85^{\beta}\right)$ & \\
\hline cgEffect: Effectiveness of the CG components & $0.63\left(3.43^{\alpha}\right)$ & $3.70\left(1.36^{\gamma}\right)$ \\
\hline Legor: legal origin ( 1 if civil law, 0 otherwise) & $1.07\left(3.57^{\alpha}\right)$ & $-0.58(-0.26)$ \\
\hline Lendr: Lend rate & $-0.06\left(-1.86^{\beta}\right)$ & $-0.213\left(-3.93^{\alpha}\right)$ \\
\hline LogGDP: GDP per capita & $0.38\left(1.64^{\gamma}\right)$ & $5.73\left(5.87^{\alpha}\right)$ \\
\hline Pricelib: Deregulation & $0.89(0.68)$ & $10.96\left(1.86^{\alpha}\right)$ \\
\hline Mgr: Rate of money growth & $0.07\left(2.55^{\alpha}\right)$ & $0.04\left(2.21^{\beta}\right)$ \\
\hline Priv: Price liberalization & $-0.03(-0.46)$ & $-0.12(-0.71)$ \\
\hline $\operatorname{reg}_{2}:$ Region 2 & $-0.08(-0.24)$ & $4.59\left(1.51^{\beta}\right)$ \\
\hline reg $_{3}:$ Region 3 & $-0.02(-0.00)$ & $7.10(1.11)$ \\
\hline reg $_{4}:$ Region 4 & $-2.02\left(-4.48^{\alpha}\right)$ & $9.01\left(1.67^{\beta}\right)$ \\
\hline Adjusted $R^{2}$ & 0.73 & 0.40 \\
\hline$F$-test ( $p$-value $)$ & $9.85^{\alpha}(0.00)$ & $9.92^{\alpha}(0.00)$ \\
\hline$n$ & 108 & 133 \\
\hline
\end{tabular}

$\alpha, \beta, \gamma$ represent statistical significance at the $1 \%, 5 \%$ and $10 \%$ levels respectively.

The aim of the second regression is to focus on the right components of CG and drive the result of the first regression. The results indicate the existence of a positive correlation between investment level and the first, the second, and the fifth components. While the third and the sixth indicators present non-significant negative relationship in the specified countries. In other words, the CG effectiveness is positively correlated with investment levels. This result corroborates our finding in the first regression. As we can see in the table, the existence of a positive relation between investment and the second CG component (Shareholders rights) indicates that more protection for the shareholders is favorable and attractive for the investment level.

Consistent with Gennaioli et al. (2012), the positive relationship between ownership concentration and CG indicates that concentrated ownership is a remedy for poor CG and allows a better protection for the rights of outside investors. This result is at the opposite of Franzini (2009) who points out a negative relationship between concentrated ownership and good CG. In the second regression, we observe the nonsignificant relationship between investment, privatization and legal origin. The result rejects the thesis of Johnson and Shleifer (2004) who establish a relationship between the two control variables. As a conclusion, our results in this section reject the null from the first hypothesis.

\subsection{Corporate Governance Level and the Growth Rate}

Results for the second hypothesis are shown in Table 2, indicating a significant coefficient for seven variables. In the same line of our previous results, the CG index and effectiveness are both significant. Our results corroborate results of Franzini (2009) on the positive relationship between the two control variables (liberalization and money growth) and the GDP growth rate. However, the lending rate has a significant negative coefficient to the dependent variable. The table shows also a better prediction power than our two first regressions for the first hypothesis. 
Table 2. Regression results for CG levels and growth rate

\begin{tabular}{|c|c|c|}
\hline & Model 1 & Model 2 \\
\hline Intercept & $0.33(1.48)$ & $0.24(1.51)$ \\
\hline$C G_{1}:$ Foundation for Cg framework & & $-7.93\left(-1.33^{\gamma}\right)$ \\
\hline$C G_{2}:$ Shareholders rights & & $6.49\left(1.92^{\beta}\right)$ \\
\hline$C G_{3}:$ Shareholder treatment & & $-1.85(-0.60)$ \\
\hline$C G_{4}:$ Shareholders role & & $-2.02(-1.17)$ \\
\hline$C G_{5}:$ Transparency & & $-6.21\left(-2.28^{\beta}\right)$ \\
\hline$C G_{6}:$ Board responsibility & & $-1.79(-0.59)$ \\
\hline cgIndex: General index & $-0.96\left(-1.61^{\gamma}\right)$ & \\
\hline cgEffect: Effectiveness of the CG components & $0.82\left(1.38^{\gamma}\right)$ & $0.73\left(1.13^{\gamma}\right)$ \\
\hline Legor: legal origin ( 1 if civil law, 0 otherwise) & $-0.05(-0.14)$ & $0.38(0.76)$ \\
\hline Lendr: Lend rate & $-0.21\left(-1.53^{\gamma}\right)$ & $-0.22\left(-1.63^{\gamma}\right)$ \\
\hline LogGDP: GDP per capita & $-0.36(-0.45)$ & $-0.42(-0.50)$ \\
\hline Pricelib: Deregulation & $1.88\left(2.00^{\beta}\right)$ & $1.76\left(1.61^{\gamma}\right)$ \\
\hline Mgr: Rate of money growth & $0.04\left(1.93^{\beta}\right)$ & $0.03\left(1.35^{\gamma}\right)$ \\
\hline Priv: Price liberalization & $-0.06(-1.13)$ & $-0.05(-0.74)$ \\
\hline reg $_{2}:$ Region 2 & $1.79\left(3.31^{\alpha}\right)$ & $2.12\left(2.43^{\alpha}\right)$ \\
\hline reg $_{2}:$ Region 3 & $1.80(0.89)$ & $2.27(1.14)$ \\
\hline reg $_{2}:$ Region 4 & $3.65\left(2.33^{\beta}\right)$ & $4.75\left(2.99^{\alpha}\right)$ \\
\hline Adjusted $R^{2}$ & 0.22 & 0.23 \\
\hline$F$-test (p-value $)$ & $10.82^{\alpha}(0.00)$ & $11.02^{\alpha}(0.00)$ \\
\hline$n$ & 108 & 133 \\
\hline
\end{tabular}

$\alpha, \beta, \gamma$ represent statistical significance at the $1 \%, 5 \%$ and $10 \%$ levels respectively.

The second model in the table reveals that the coefficients for CG1, CG2 and CG5 are significant, indicating a strong high correlation to GDP. Regarding results for the second hypothesis, we argue the existence of a negative relationship between CG components and GDP growth. Consequently, we reject the null of the second hypothesis. There is evidence if the CG system is weak, all mechanisms don't affect the GDP growth.

\section{CONCLUSIONS}

The research examines the relationship between the CG practices, investment levels and GDP growth. After testing the hypothesis, we find two major results. First, we show that good $\mathrm{CG}$ practices are positively correlated to investment level and GDP in the country. The other variables are the same as expected by literature. Second, we expose, that the weak legal system of the country can explain the inefficiencies in the CG mechanisms. This paper seeks to describe and analyze the connection between investment, GDP growth and CG in theory and in practice. Our findings negate some of the preliminary anticipations regarding the effect of CG on investment and GDP growth. After testing the hypotheses, we find a negative correlation between the dependent variables and CG. The common drivers of this negative correlation in both regressions are the following CG groups: "ensuring the basis for an effective CG framework" and "disclosure and transparency". On the other hand, most control variables behave as expected and predicted by literature, which increases the reliability of the study.

\section{AUTHOR BIOGRAPHY}

Taruk Miloud is Professor of Finance at INSEEC Business School. His research has been published in a number of top-tier international journals. He may be reached at tmiloud@gmail.com

\section{REFERENCES}

Agrawal, A., and N. Mandelker, 1990, Large shareholders and the monitoring of managers: The case of antitakeover charter amendments, The Journal of Financial and Quantitative Analysis 25(2), 143-161.

Barca, F., and S. Trento, 1997, State ownership and the evolution of italian corporate governance, Industrial and Corporate Change 6(3), 533-559.

Cioffi, JW., 2000, Governing globalization? The state, law, and structural change in corporate governance, Journal of Law and Society 27(4), 572-600. 
Denis, D., and A. Sarin, 1999, Ownership and board structures in publicly traded corporations, Journal of Financial Economics 52(2), 187-223.

Fama, E., 1980, Agency problems and the theory of a firm, Journal of Political Economy 88(2), 288-307.

Fama, E., 1980, Agency problems and the theory of the firm, Journal of Political Economy 88(2), 288-307.

Fama, E., and M. Jensen, 1983, Separation of ownership and control, Journal of Law and Economics 26(2), 301-326.

Franks, J., and C. Mayer, 1998, Bank control, takeovers and corporate governance in germany, Journal of Banking and Finance 22(1385-1403).

Franzini, S., 2009, Corporate governance in theory and practice, Journal of Politics and International Affairs 5(Spring), 77-93.

Gennaioli, N., A. Shleifer, and R. Vishny, 2012, A model of shadow banking, The Journal of Finance 68(4), $1331-1363$.

Güler, A., and D. Croxther, 2009. Global perspectives on corporate governance and csr (Gower, England).

Hart, O., 1995, Corporate governance: Some theory and implications, The Economic Journal 105(430), 678-689.

Jensen, M., 1986, Agency costs of free cash flow, corporate finance, and takeover, American Economic Review 76(2), 323-329.

Jensen, M., 1993, The model industrial revolution, exit, and the failure of internal control systems, Journal of Finance 48(3), 831-880

Jensen, M., and W. Meckling, 1976, Theory of the firm: Managerial behavior, agency costs and ownership structure, Journal of Financial Economics 3(4), 305-360.

John, K., and L. Senbet, 1998, Corporate governance and board effectiveness, Journal of Banking and Finance 22(4), $371-403$.

Johnson, S., and A. Shleifer, 2004, Privatization and corporate governance, National Bureau of Economic Research 13-34.

La Porta, R., F. Lopez-De-Silanes, and A. Shleifer, 1999, Corporate ownership around the world, The Journal of Finance 54(2), 471-518.

La Porta, R., de-Silanes. Lopez, A. Shleifer, and R. Vishny, 2000, Investor protection and corporate governance, Journal of Financial Economics 58(1-2), 3-27.

Mitton, T., 2002, A cross-firm analysis of the impact of corporate governance on the east asian financial crisis, Journal of Financial Economics 64(2), 215-241.

Morck, R., A. Shleifer, and R. Vishny, 1988, Management ownership and market valuation: An empirical analysis, Journal of Financial Economics 20(1-2), 293-316.

Morris, D.M., 1989, Family businesses: High candidates for financial distress, Small Business Reports 14(3), 43-45.

Shleifer, A., and R. Vishny, 1997, A survey of corporate governance, The Journal of Finance 82(2), 737-783.

Solomon, J., 2010. Corporate governance and accountability (Wiley).

Tirole, J., 2001, Corporate governance, Econometrica 69(1), 1-35.

Weisbach, M., 1988, Outside directors and ceo turnover, Journal of Financial Economics 20(1-2), 431-460.

Zahra, S., and J. Pearce, 1989, Boards of directors and corporate financial performance: A review and integrative model, Journal of Management 15(2), 291-334. 


\section{NOTES}

